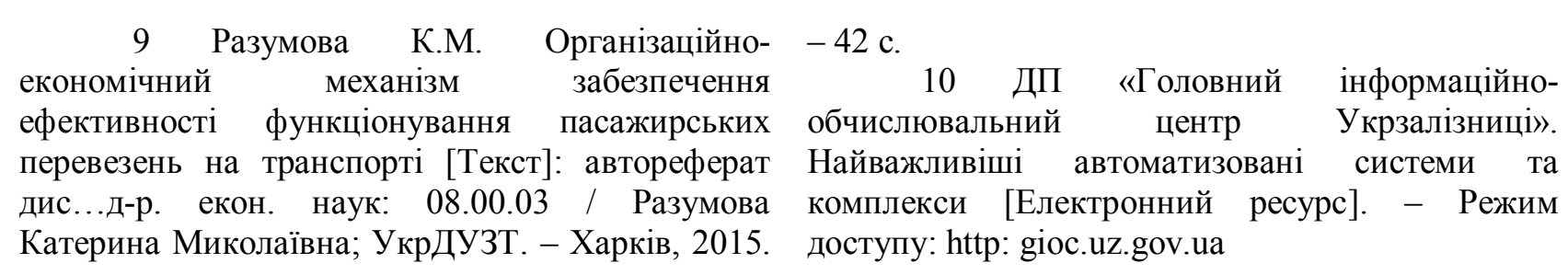

Експерт редакційної колегії к.е.н., доцент УкрДУЗТ Зубенко В.О.

УДК 656.224.072.44

\title{
МЕТОДИ ОРГАНІЗАЦІї ТУРИСТИЧНИХ ПЕРЕВЕЗЕНЬ
}

\author{
Бараш Ю.С., д.е.н., професор, \\ Марценюк Л.В., к.е.н., доцент (ДНУЗТ)
}

\begin{abstract}
Авторами розроблені нові методи організаџї туристичних перевезень по широким та вузьким залізничним коліям, які враховують схему існуючих або нових залізничних колій України та пропонують три види організаиії руху туристичних поїздів: човниковий, по кільию та комбінований.

Крім того, для оптимального планування туристичних подорожей по залізниці вперме розроблено методичний підхід щэоо визначення загального часу туристичних подорожей різної тривалості.
\end{abstract}

Ключові слова: залізничний транспорт; залізничний туризм; залізничні туристичні перевезення; трансфер; вузька колія; туристична подорож

\section{МЕТОДЫ ОРГАНИЗАЦИИ ТУРИСТИЧЕСКИХ ПЕРЕВОЗОК}

Бараш Ю.С., о.э.н., профессор, Марценюк Л.В., к.э.н., доцент (ДНУжТ)

\begin{abstract}
Авторами разработаны новые методы организации туристических перевозок по широким и узким железнодорожным путям, которые учитывают схему существующих или новых железнодорожных путей Украины и предлагают три вида организации движения туристических поездов: челночный, по кольиу и комбинированный.

Кроме того, для оптимального планирования туристических путешествий по железной дороге впервые разработан методический подход к определению общего времени туристических путешествий различной продолжительности.

Ключевые слова: жжелезнодорожсный транспорт; ж⿻елезнодорожнный туризм; железнодорожные туристические перевозки; трансфер; узкоколейная жселезная дорога; туристическое путешествие
\end{abstract}

\section{METHODS OF TOURIST TRAFFIC}

\author{
Barash Y.S., Doctor of Economic Sciences, professor, \\ Martsenyuk L.V. Candidate of Economic Sciences \\ (Dnipropetrovsk National University of Railway Transport)
}

Examples of successful operation of tourism is in many developed countries. According to the authors, in Ukraine one of the areas of effective fundraising domestic and foreign investors have become tourist industry.

(C) Бараш Ю.C., 
The authors have developed new methods of organization of tourist traffic on the wide and narrow railway tracks, which take into account the scheme of existing or new railways of Ukraine and offer three types of traffic organization of tourist trains: shuttle, a ring and combined.

In addition, for optimal planning of tourist travel by rail for the first time developed a methodical approach to determining the total time tourist trips of varying duration.

Rationally applied measures proposed by the authors directions managing tourist flows will increase revenues to the budget from domestic tourism. trip

Keywords: rail; railway tourism; rail travel transportation; transfer; narrow-gauge railway; tourist

\section{Вступ.}

За часи існування Радянського Союзу залізничний транспорт приділяв значну увагу пасажирським туристичним перевезенням. Але ці перевезення були організовані тільки по широкій залізничній колії. Туристичні поїзди в основному не мали спеціального рухомого складу, а формувалися із звичайних купейних вагонів 3 включенням до туристичного поїзду кількох вагонів ресторанів. Крім того, кожного літа організовувалися піонерські табори на колесах, які мали зупинки на березі моря або в інших містах відпочинку. Управління туристичними пасажирськими перевезеннями виконували пасажирські служби окремої залізниці. Вони надавали для перевезення рухомий склад, забезпечували заправку вагонів водою на час подорожі, організовували технічних супровід та поточний ремонт рухомого складу, встановлювали необхідне обладнання на місцях стоянки туристичних поїздів i організовували харчування туристів у місцевих вокзальних ресторанах.

В данні часи ПАТ «УЗ» майже не займається туристичними перевезеннями пасажирів, оскільки в неї не вистачає пасажирських вагонів необхідної якості. Крім того, організація туристичних перевезень потребує зараз підвищеного комфорту, більшої швидкості, спеціального рухомого складу, оснащеного вакуумними або біотуалетами, кондиціюванням повітря, Інтернетом, телебаченням, якісним харчуванням та ін. Починаючи 32016 року Укрзалізниця почала реформувати свою організаційну структуру, за якою передбачалося утворення двох секторів: монопольного та конкурентного. До монопольного сектору була віднесена основна діяльність українських залізниць - перевезення пасажирів у далекому, регіональному та приміському сполученні, а також вантажні перевезення та організаційні структури, що їх обслуговують. До конкурентного сектору була віднесена інша діяльність, яка не пов'язана 3 процесами перевезень.

\section{Постановка проблеми.}

3 погляду на сказане вище, надання туристичних послуг може бути віднесено до монопольного сектору, якщо Укрзалізниця буде займатися тільки перевезенням туристів (трансферні послуги), або до конкурентного сектору, якщо на базі Укрзалізниці буде утворена туристична компанія, яка буде займатися усім комплексом туристичних послуг.

Можливий ще варіант організації туристичних компаній, який передбачає утворення самостійних юридичних осіб, які будуть орендувати в ПАТ «УЗ» нитки графіку та у власному рухомому складі виконувати туристичні залізничні перевезення.

Для раціонального вирішення вказаних проблем необхідно розробити комплексну науково-обгрунтовану методику, яка буде включати низку наукових підходів, принципів та наукових розробок щодо визначення туристичного бізнесу в Україні з використанням існуючих вузьких та широких залізничних колій. Такої методики проведення дисертаційних досліджень в Україні ще не було. Така організація туристичних перевезень передбачає більш досконале знайомство 3 чарівною природою регіонів України, місцевими озерами, заповідниками, замками, визначними історичними пам'ятками, проживання у готелях, дегустацію вин, активний відпочинок, катання на лижах у горах та рибалку. Комплекс послуг передбачає зупинку на кілька днів у вказаних місцях на термін, який самостійно обирають туристи, а залізниця за встановленим заздалегідь графіком буде перевозити їх 3 одного місця відпочинку до іншого.

За останні десятиліття залізничний туризм майже зник на теренах України і потребує нових принципових підходів до його розвитку.

Аналіз останніх досліджень і публікацій.

Питаннями розвитку та реформування транспорту та туристичної галузі, а також побудовою нових організаційних структур та 
форм управління займалися вітчизняніі вчені: В.В. Абрамов [1], Т. Алексіюк [2], Н.О. Алєшугіна [3], Ю. С. Бараш [5], Л.Г. Богуш, О.М. Гненний, В. Г. Гулясв [6], О. Дем'янчук [8], А.О. Дергоусова [9], О.Г. Дейнека [7], В.Ф. Кифяк, С.В. Мочерний, О. Нагорнюк [15], I.М. Писаревський [17], П.О. Пшінько [11], B.I. Стрілець [18], T.I. Ткаченко, С. Тишковець [19], Т.М. Ореховська, Ф.Е. Поклонський, Н.В. Чорненька [21], І.М. Школа та іноземні автори [22-25].

Так, Дергоусова А.О. у своїй роботі запропонувала нове визначення терміну «залізничний туризм» та нову класифікацію видів туризму. Крім того, автором запропоновано новий методичний підхід до визначення доцільності організації

конкурентоспроможності залізничних подорожей за різними напрямками, що базується на визначенні i використання коефіцієнтів насиченості напрямку, привабливості туру та ефективної туристичної вартості та дає можливість організації більш конкурентоспроможних залізничних подорожей порівняно 3 іншими. Також у іiі наукових дослідженнях визначені фактори конкурентоспроможності подорожей, які враховують особливості організації залізничного туризму, що найбільше впливають на задоволення потреб потенційних споживачів за рахунок виділення найвагоміших факторів [9].

Є.І. Балака та Г.О. Сіваконева пропонують впровадити розвиток залізничного туризму на основі кластеризації. Вони вважають, що розвиток залізничного туризму в України неможливий без диверсифікації діяльності залізничного транспорту у суміжний сегмент господарювання - туризм. Авторами запропоновано провести диверсифікацію за рахунок створення транспортно-туристичного кластеру, який очолить Міністерство інфраструктури. При цьому автори пропонують провести диверсифікацію пасажирського господарства у три етапи: спочатку визначити учасників кластеру, потім об'єднати асоціативні товариства в акціонерні товариства i на заключному етапі створити організацію холдингових компаній [4].

Дейнека О.Г. задля підвищення конкурентоспроможності пасажирських перевезень залізничних транспортом пропонує розширити коло послуг на вокзалах та станціях. Він звертає увагу на те, що досі в України немає достатнього практичного та теоретичного досвіду для успішної диверсифікації підприємств залізничного транспорту. Автор вважає, що спочатку потрібно визначити стратегічну мету діяльності залізничного транспорту, потім розробити критерії диверсифікації, спираючись на позитивний досвід закордонних компаній [7].

Автори В.Г. Кузнецов, П.О. Пшінько, I. В. Кліменко, А. В. Гуменюк, С. М. Загорулько у своїй науковій роботі визначили перспективи розвитку залізничного туризму України на вузькоколійних лініях Закарпаття [11].

Н.О. Алєшугіна, аналізуючи транспортну інфраструктуру, зробила висновок, що транспортна складова туристичного потенціалу України в сучасних умовах сприяе його зміцненню лише в тому сенсі, що система транспортних мереж має яскраво виражений транзитний характер. Отже, велика кількість територій, забезпечених різноманітними рекреаційними ресурсами, має хорошу транспортну доступність для туристів та екскурсантів, як вітчизняних, так і зарубіжних. Щодо стану транспортної інфраструктури, то для того, щоб вона сприяла ефективному використанню та нарощуванню туристичного потенціалу, необхідне удосконалення усіх іiі складових як у кількісному, так i, особливо, в якісному плані. Крім того, активне залучення різних видів транспорту до туристичного обслуговування дозволить ефективно розвивати різноманітні сфери та види туристичного бізнесу, диверсифікувати спектр надаваних туристичних послуг [3].

Р.Г. Коробйова акцентує увагу на відродженні залізничного транспорту, а саме: оновленні інфраструктури та рухомого складу за рахунок приватних інвесторів [10].

Хаустова В.С., Горбатова Є.Ф. відзначають, що туристичні об'єкти все ще залишаються незатребуваними із-за низького рівня розвитку інфраструктури туристичних послуг, а інфраструктура не відновлюється із-за незацікавленості інвесторів, адже держава жодним чином не стимулює їх. Серед напрямів покращення ситуації на українському ринку туристичних послуг автори пропонують: відновлення інфраструктури, розвиток соціальних туристичних програм, удосконалення інформаційної політики, реконструкцію туристичних об'єктів та інші [20].

Новіцька I.В. вважає розвиток туристичних маршрутів одним 3 ефективних перспективних напрямків діяльності залізниць 
України та наполягає на дотриманні європейських стандартів якості послуг, адже тільки завдяки високому сервісу вдасться підвищити конкурентоспроможність залізничного транспорту та туристичної галузі i, як наслідок, привабити велику кількість туристів [16].

\section{Виділення невирішених частин.} Безумовно, кожен зі згаданих вчених вніс свій істотний вклад у дослідження 3 вищевказаних питань, але потрібно відзначити, що жоден з них задля підвищення конкурентоспроможності пасажирських перевезень залізничним транспортом не запропонував нові методи організації туристичних перевезень різної тривалості залізницями України.

\section{Мета дослідження.}

Метою дослідження $є$ розробка нових методів організації туристичних перевезень по широким та вузьким залізничним коліям, які б врахували схему існуючих або нових залізничних колій України, а також розробка універсального методичного підходу щодо визначення загального часу одноденних, дводенних та багатоденних туристичних подорожей задля оптимального планування туристичних подорожей.

\section{Виклад основного матеріалу.}

Залізничні туристичні перевезення мають свою специфіку, оскільки здійснюються тільки по залізничним рейкам. 3 цього випливає, що їх маршрут завжди співпадає з напрямком колії. Це дуже обмежує організацію туристичних маршрутів і значно скорочує кількість екскурсій. В той же час залізничні туристичні перевезення мають суттєву перевагу перед всіма іншими наземними видами туристичних подорожей, оскільки дозволяють надавати туристам якісний комфорт під час руху поїзда (ночівлю у зручних купе, свободу пересування по вагонах, організацію харчування в ресторані, вакуумні туалети, салон для проведення зустрічей з гідом, телевізори, кондиціювання та Wi-Fi) [12,13,14].

Зважаючи на схему існуючих колій можна визначити наступні методи організації туристичних перевезень (рис.1).

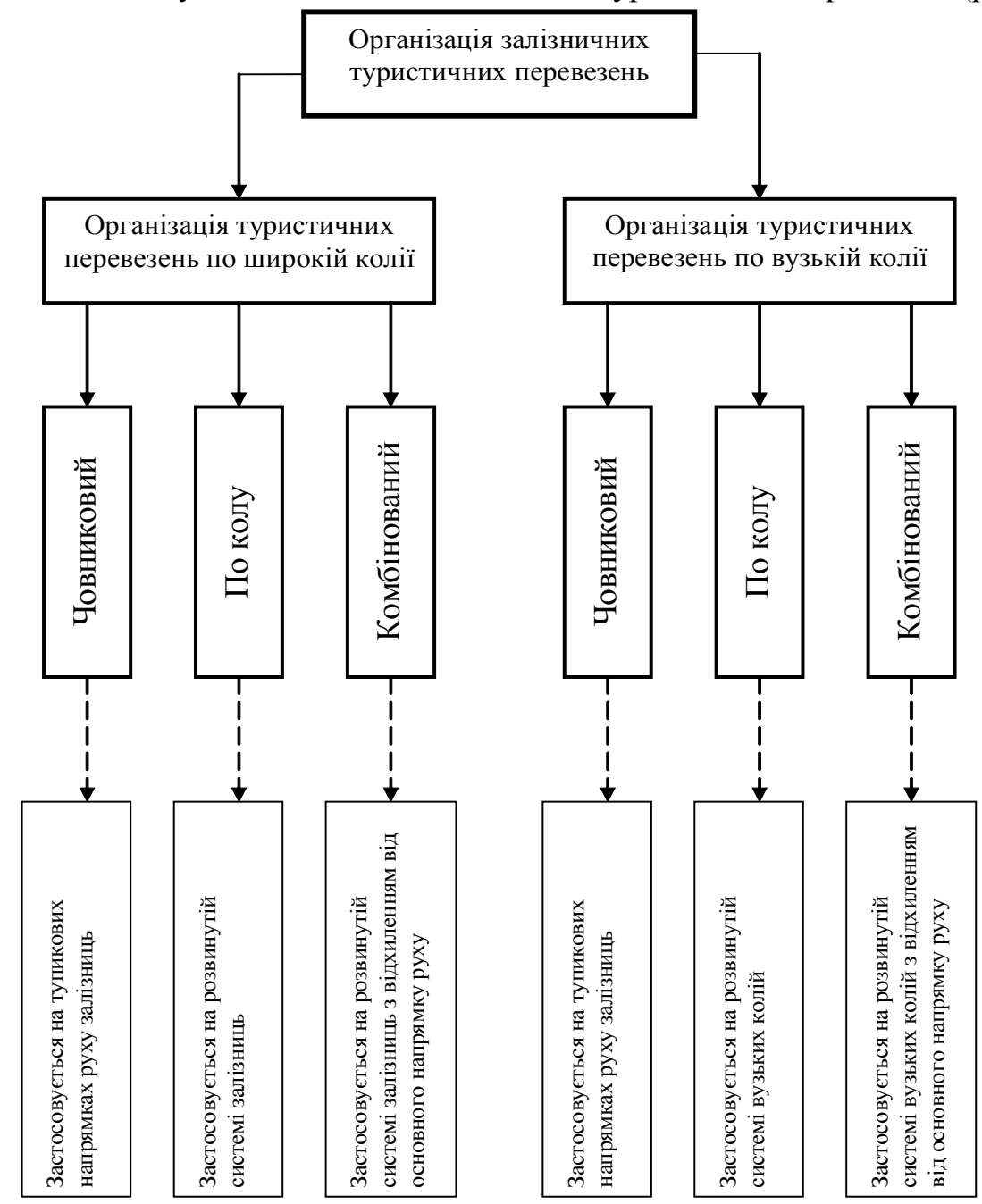

Рис. 1. Методи організації туристичних перевезень. Джерело: розробка авторів 
По широкій колії:

1. Човниковий - застосовується на тупикових напрямках руху залізниць.

2. По кільцю - застосовується на розвинутій системі залізниць.

3. Комбінований - застосовується на розвинутій системі залізниць 3 відхиленням від основного напрямку руху.

По вузькій колії:

1. Човниковий - застосовується на тупикових напрямках руху залізниць.

2. По кільцю - застосовується на розвинутій системі вузьких колій.

3. Комбінований - застосовується на розвинутій системі вузьких колій з відхиленням від основного напрямку руху.

Крім напрямку руху поїздів на туристичні подорожі впливає кількість зупинок на маршруті термін перебування туристів на кожній зупинці, який в свій час залежить від кількості туристичних екскурсій, харчування у ресторанах, кафе, колибах та ночівлю у готелях.

Кількість зупинок на маршруті слід розраховувати залежно від втоми туристичної групи, бажання повернутися до місця відпочинку, яке може бути у поїзді, під час харчування або безпосередньо на екскурсії.

Нижче запропоновані різні схеми організації туристичних подорожей 3 урахуванням напрямку залізничного маршруту, кількості туристичних екскурсій протягом дня та загального терміну туристичної подорожі.

Будь-які туристичні подорожі по залізницям передбачають комфортні умови, до яких слід віднести:

загальну тривалість одноденної екскурсії, яка не повинна перевищувати - 18 годин;

- кількість зупинок поїзда для огляду визначних пам'яток, заповідників, мальовничих озер, зон відпочинку та харчування повинна розраховуватися 3 урахуванням загального терміну подорожі, середньої швидкості руху поїзда, необхідного часу на проведення кожної екскурсії;

- в першій половині подорожі кількість екскурсій мусить бути більшою ніж у другій половині, оскільки після обіду та 15 годин дня туристи почувають себе втомленими і менш активні;

- швидкість руху поїзда у зворотному напрямку може бути більшою ніж у прямому русі i досягати 100 км/год. Для вузьких колій швидкість поїздів розраховується залежно від профілю колії;

- якщо подорож триває два дні, то у кінці маршруту першого дня мусить бути запланована зупинка, яка передбачає відпочинок туристів у готелі та безкоштовний ужин, вартість якого включено у вартість путівки;

- кількість туристичних екскурсій на такому маршруті не може бути великою, оскільки термін однієї зупинки може тривати від 1,5 годин до 5 годин. А коли на певній зупинці передбачено харчування то час зупинки збільшується ще на 1,5 години;

- організація круїзної туристичної подорожі передбачає максимальні комфортні умови для туристів, а саме купе для відпочинку 3 кондиціюванням повітря, телебачення та Wi-Fi, харчування у вагонах-ресторанах, роботу гіда, трансферні перевезення до місць проведення екскурсій комфортабельними туристичними автобусами, періодичне харчування у місцевих ресторанах та ін.

Організація туристичних перевезень при обслуговувані короткострокових екскурсій.

Одноденна оглядова залізнична подорож (рис. 2) призначена для знайомства 3 пам'ятними, історичними місцями, мальовничою природою регіону та місцями відпочинку. Такі подорожі можна організовувати човниковим методом на тупиковому напрямках руху залізниць, по кільцю на розвинутій системі залізниць так i комбінованим методом на розвинутій системі залізниць з відхиленням від основного напрямку pyxy.

3 урахуванням сказаного вище та мінімального проміжку часу між зупинками поїзда на маршруті - 2 години, можна розрахувати загальний термін туристичної подорожі (1), або кількість зупинок для проведення екскурсій (2). 


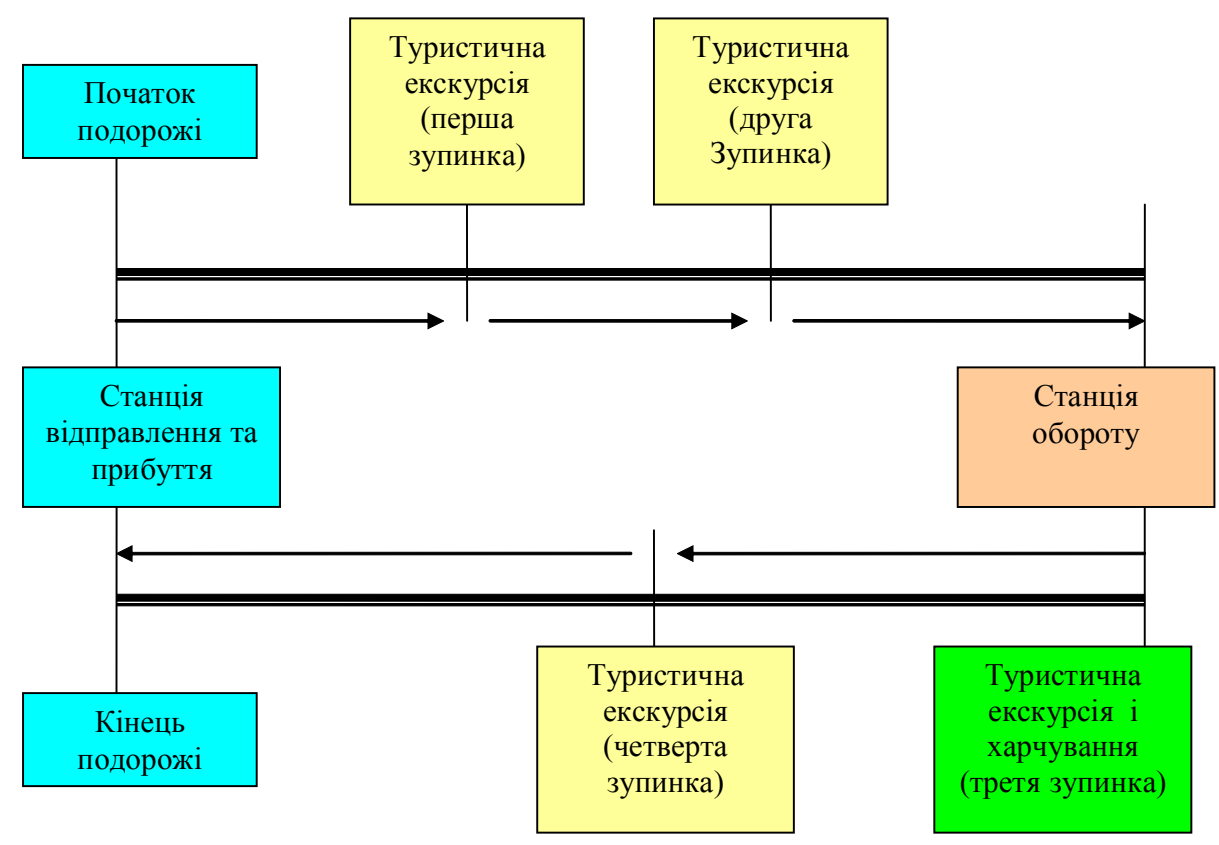

Рис. 2. Схема організачї туристичних оглядових перевезень по залізничним коліям за умови одноденної поїздки. Джерело: розробка авторів (кількість зупинок показана умовно)

$$
t_{\text {заг }}^{\text {одн }}=\frac{S^{n p}}{V_{c}^{n p}}+\frac{S^{3 в}}{V_{c}^{3 в}}+n \cdot t_{c е p}^{\text {екск }}+t_{x a p u} \leq 18
$$

де $t_{\text {заг }}^{o \partial н}$ - розрахунковий час туристичної подорожі при організації одноденних екскурсій по залізничним коліям, год.;

$S^{n p} \quad-$ протяжність туристичного маршруту в прямому сполученні, км;

$S^{38}-$ протяжність туристичного маршруту в зворотному сполученні, км;

$V_{c}^{n p}$ - середня швидкість руху поїзду в прямому русі, км/год.;

$V_{c}^{n p}-$ середня швидкість руху поїзду в $t_{c p}^{\text {екск }}$ - середній час екскурсії підчас проведення туристичних подорожей по залізничним коліям в прямому та зворотному русі, год.;

$t_{\text {харч }}-$ час харчування туристів в ресторанах та кафе підчас проведення туристичних подорожей по залізничним коліям в прямому та зворотному русі, год.;

$\boldsymbol{n}$ - кількість екскурсій або зупинок на туристичному маршруті, од; зворотному русі, км/год.;

$$
n=\left(t_{\text {заг }}^{o \partial н}-\frac{S^{n p}}{V_{c}^{n p}}+\frac{S^{38}}{V_{c}^{38}}+t_{x a p y}\right) / t_{c p}^{e \kappa c \kappa}
$$

Крім одноденних оглядових екскурсій по залізничним коліям ПАТ «Українська залізниця» може використовувати дводенні подорожі або подорожі вихідного дня. Слід сказати, що такі подорожі в Україні майже не існують. 
В цьому разі маршрут вихідного дня будується за трьома принципами: ночівля в поїзді, а харчування в місцевому ресторані; ночівля в поїзді, а харчування у вагоні ресторані; ночівля та харчування в готелі.

Перший варіант туристична компанія використовує при відсутності власних або орендованих вагонів-ресторанів. Другий - при наявності у туристичному поїзді власного вагону-ресторану, а третій - коли у складі поїзда відсутні вагони для ночівлі туристів та вагонівресторанів.

В загальному вигляді схема організації туристичних оглядових подорожей по залізничним коліям України буде мати вид (рис. 3), формула для розрахунку загального терміну подорожі набуде виду (3)
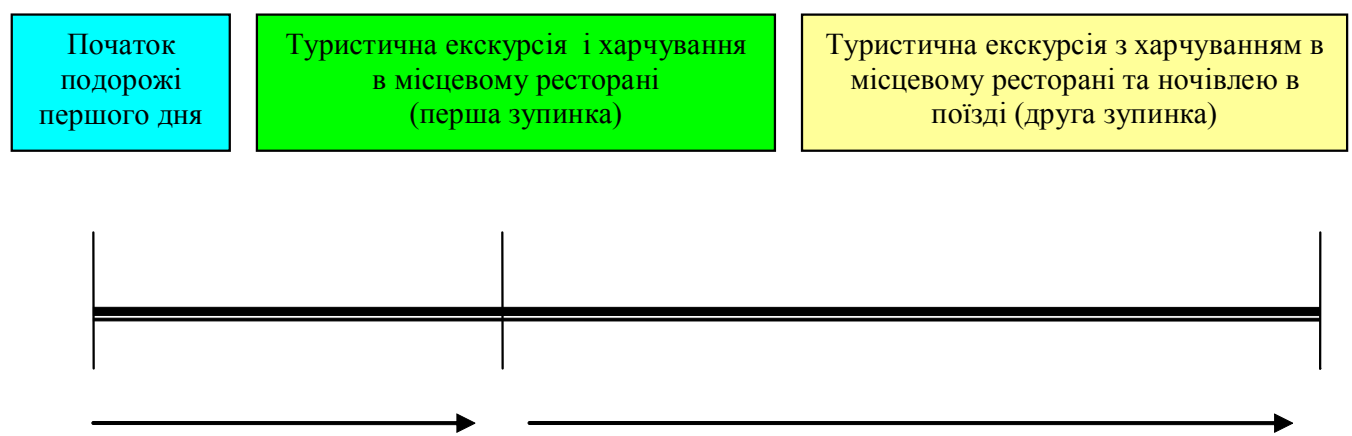

Станція відправлення та прибуття

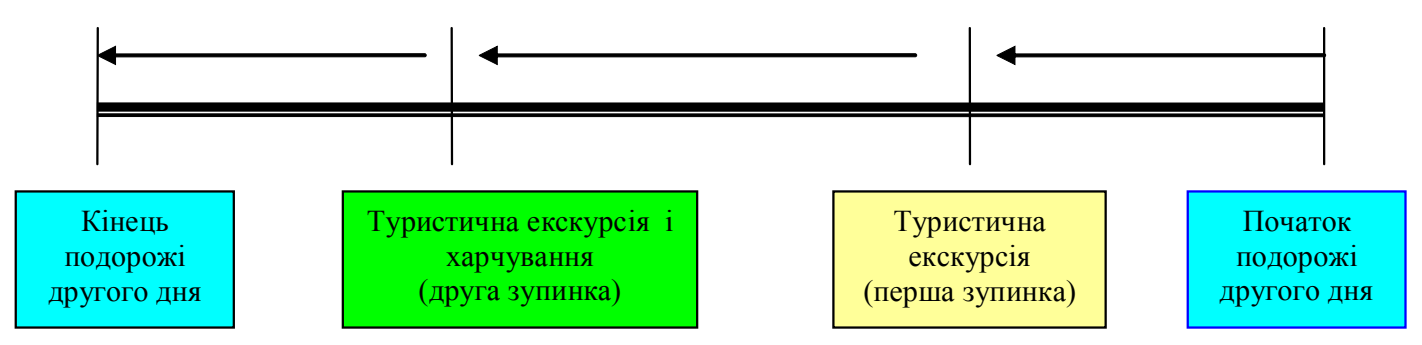

Рис. 3. Схема організаиії туристичних оглядових подорожей по залізничним коліям за умови дводенної поӥздки. Джерело: розробка авторів (кількість зупинок показана умовно).

$$
t_{\text {заг }}^{\partial д н}=\frac{S^{n p}}{V_{c}^{n p}}+\frac{S^{36}}{V_{c}^{36}}+\sum_{k=1}^{n} t_{\text {екск }}^{k}+\sum_{l-1}^{b} t_{x a p u}^{l}+t_{n p 2} \leq 38
$$

де $t_{\text {заг }}^{\partial д в ~}-$ розрахунковий термін

туристичної подорожі при організації дводенних екскурсій по залізничним коліям, год.;

$$
\sum_{k=1}^{n} t_{\text {екск }}^{k} \text { - загальний термін екскурсій }
$$

підчас проведення туристичних подорожей по вузькоколійній залізниці в прямому та зворотному русі, год.;
Станція обороту

$$
\sum_{l=1}^{b} t_{x a p ч}^{l}-\text { загальний термін харчування }
$$
туристів в ресторанах та кафе (якщо відсутній вагон ресторан) при дводенній подорожі, год.;

$t_{n p 2}$ - термін проживання туристів в готелі або у вагонах поїзда при дводенній подорожі, год.

$b$ - кількість харчувань у ресторанах або кафе на туристичному маршруті при дводенній подорожі, од. 
Організація туристичних перевезень при організаиї багатоденних туристичних

$$
\text { подорожей }
$$

Організація багатоденних туристичних подорожей по залізничним коліям суттєво відрізняється від оглядових екскурсій, оскільки виконується спеціальним рухомим складом, що має комфортні умови для туристичної подорожі. Вище було сказано, що при організації круїзних туристичних подорожей ночівля, відпочинок та харчування передбачено у поїзді, але інколи туристи можуть проживати у готелях та харчуватися в ресторанах. Термін таких подорожей може становити 14 діб.

На рисунку 4 показана специфіка круїзних туристичних подорожей, що пов'язана із кількістю туристичних екскурсій на добу та їх тривалістю. Як правило, таких екскурсій може бути одна добу з відпочинком та харчуванням в кафе або ресторані. Велика кількість туристичних екскурсій протягом дня може визивати втому та небажання приймати участь у наступній екскурсії.

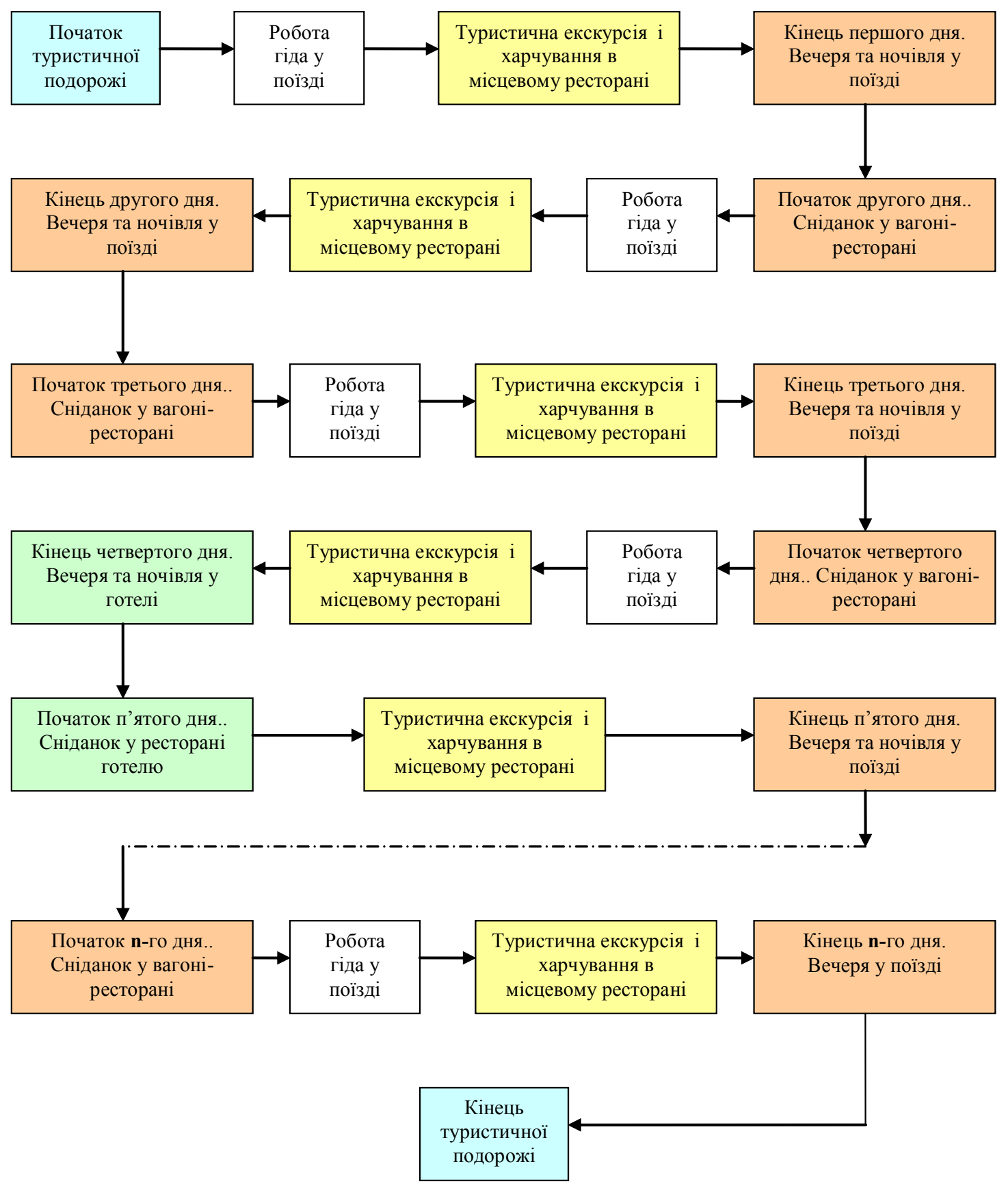

Рис. 4. Схема організаиії туристичних круїзних подорожей по залізничним коліям. Джерело: розробка авторів (кількість зупинок показана умовно). 
Методика розрахунку загального терміну туристичної круїзної залізничної подорожі залежно від кількості зупинок (екскурсій) на маршруті, місць харчування та ночівлі у готелях 3 урахування терміну очікування відправки поїзду за графіком представлена у формулі (4).

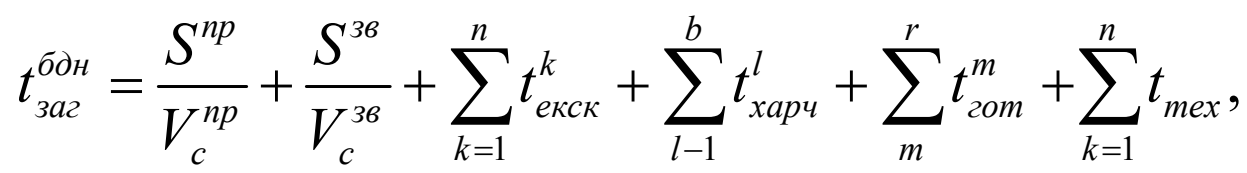

де $\sum_{k=1}^{r} t_{\text {гот }}^{m}-$ термін відпочинку туристів в

готелях, що передбачені путівкою, год.;

$\sum_{k=1}^{n} t_{\text {гот }}^{k} \quad$ сумарний термін очікування відправки поїзду за графіком на усіх станціях маршруту, год.

Трансферні перевезення туристів.

Залізничні туристичні перевезення завжди пов'язані 3 трансферними перевезеннями, мета яких доставити туристів від залізничного вокзалу (місця відстою поїзда) до місця проведення екскурсії, ресторану або кафе і якщо потрібно до готелю, в якому вночі будуть проживати туристи. В зворотному напрямку ці перевезення мають намір доставити туристів до залізничного вокзалу або місця відстою поїзда. Як правило трансферні перевезення виконуються комфортабельними туристичними автобусами або малими автобусами, які як правило мають зручні м'які сидіння, кондиціювання повітря, Wi$\mathrm{Fi}$ та оснащені радіо зв'язком для проведення екскурсій.

У районах, які обслуговуються туристичним вузькоколійним рухомим складом, доставка туристів може здійснюватися кількома видами трансферу: автомобільним (автобуси, рельсомобілі) та малою авіацією (гелікоптерами).

Якщо автобусні та маршрутні трансфери всі реально собі уявляють, то термін рельсомобілі потребує додаткових пояснень. Рельсомобіль це будь-який автобус, що може пересуватися одночасно по залізничним рейкам. $€$ багато конструкцій рельсомобілей, які можуть пересуватися по широкій та європейській колії, але конструкції рельсомобілей, що можуть курсувати по вузьким коліям, потребують розробки. В той же час використання рельсомобілей дає можливість доставляти туристів від залізничних станцій до готелів та місць відпочинку по широкій або вузькій колії в районах, де автобусний рух стає проблематичним в поганих погодних умовах.
Інколи для швидкої доставки туристів 3 аеропортів та залізничних станцій до вузькоколійної залізниці та готелів, що знаходиться у важкодоступних районах використовуються гелікоптери. Але цей вид трансферу дорогий і не зовсім надійний, оскільки залежить від погоди.

Автори пропонують удосконалити класичне термінологічне поняття «трансферу (надання транспортних засобів для забезпечення зустрічей-проводів туристів)». На наш погляд, це термінологічне поняття мусить визначатися так: «трансферні перевезення - це вид транспортної діяльності, який має на меті перевезення туристів від будь-якого основного виду транспорту до місць проведення планового відпочинку (екскурсії, готелів, спокійного та активного відпочинку, ресторанів, магазинів та ін.) в прямому та зворотному напрямку і виконується туристичними та малими автобусами, звичайними автомобілями, малою авіацією, катерами та моторними човнами».

\section{Висновки.}

Наукова новизна та практична значимість. В даній роботі набули подальшого розвитку методи організації туристичних перевезень по широким та вузьким залізничним коліям, які враховують схему існуючих або нових залізничних колій України та пропонують три види організації руху туристичних поїздів: човниковий, по кільцю та комбінований, що дозволить оптимізувати ефективність туристичних маршрутів.

Крім того, вперше розроблено методичний підхід щодо визначення загального часу одноденних, дводенних та багатоденних туристичних подорожей, який базується на врахуванні терміну руху залізничного поїзда на маршруті, кількості екскурсій та часу перебування туристів на них, терміну перебування в готелях, в ресторанах, кафе та очікування відправки поїзду за графіком, що дозволить заздалегідь планувати різні види 
туристичних подорожей по залізниці та мінімізувати витрати на їх організацію.

\section{СПИСОК ЛІТЕРАТУРИ}

1. Абрамов В. В. Історія туризму : підручник / В. В. Абрамов, М. В. Тонокошкур. Харків : ХНАМГ, 2010. - 294 с.

2. Алексіюк Т. Може хтось допоможе: Зарічненщина туристична: [Про розробку інноваційного туристичного продукту «Поліський трамвай» щодо вузькоколійної залізниці «Антонівка-Зарічне»] / Т. Алексіюк // Полісся. - 2009. - N4 /29січня/. - С. 2.

3. Н.О. Алєшугіна. Транспортна інфраструктура як складова туристичного потенціалу України. - «Ефективна економіка». Вісник Дніпропетровського державного аграрноекономічного університету. - №3, 2009 p.

4. Балака С.I, Сіваконева Г.О. Організаційний аспект відродження та розвитку залізничного туризму на основі кластеризації. Технологічний аудит та резерви виробництва. № $15,2014 \mathrm{p}$.

5. Бараш Ю. С. Розвиток залізничного туризму в України / Ю. С. Бараш, А. О. Кравченко, О. С. Яснецов // Зб. наук. праць Дніпропетр. нац. ун-ту зал.трансп. ім. акад. В. Лазаряна «Проблеми економіки трансп.». Дніпропетровськ, 2014. - Вип. 8. - С. 7-11.

6. Гуляєв В. Г. Організація туристичних перевозок / В. Г. Гуляєв. - Москва Фінанси і статистика. - 2001. - 512 с.

7. Дейнека О.Г. Наукові підходи до диверсифікації підприємств залізничного транспорту. - Вісник економіки транспорту і промисловості. - № 38, 2012. - С. 163-165.

8. Дем'янчук О. Туристична галузь [області] - мішок для наповнення бюджету / O. Дем’янчук // Вісті Рівненщини. - 2009. - №39/24 верес./. - С. 7.

9. Дергоусова А.О. Формування стратегії розвитку залізничного туризму [Текст] : дис. к.е.н.: спец. 08.00.04. - економіка та управління підприємствами (за видами економічної діяльності) / А.О. Дергоусова. - Х. : УкрДАЗТ, 2012. - $216 \mathrm{c}$.

10. Коробйова Р.Г. Потенціал розвитку залізничного туризму в Україні. - Збірник наукових праць ДНУЗТ ім. акад. В. Лазаряна, № 20,2015 p. - C. $70-74$.

11. Кузнецов В.Г., Пшінько П.О., Кліменко I. В., Гуменюк А. В., Загорулько С. М. Перспективи розвитку залізничного туризму
України на вузькоколійних лініях Закарпаття. Наука та прогрес транспорту. - Вісник Дніпропетровського національного університету залізничного транспорту. - №4(58), 2015. - С. 2333.

12. Марценюк Л. В. Збереження історичної залізничної спадщини в контексті захисту національних інтересів України. «Економіка та держава». Міжнародний науково-практичний журнал. - м. Київ. - №9, вересень 2015 р. - С. 28 $-32$.

13. Марценюк Л. В. Напрямки розвитку внутрішнього туризму в Україні. - Наука та прогрес транспорту. Дніпропетровського національного університету залізничного транспорту імені академіка В. Лазаряна. - № 6(54) 2014 р. - С. 41 - 52.

14. Марценюк Л. В. Основні засади розвитку транспортного туризму в Україні / Л. В. Марценюк // Вісн. Дніпропетр. нац. у-ту залізн. трансп. ім. акад. В. Лазаряна. - Д., 2013. - Вип. 47. - С. 24-32.

15. Нагорнюк О. Вузькоколійка. 106 кілометрів Полісся. - Рівне, 2008. - 60с.

16. Новіцька І.В. Європейський досвід у розвитку залізничного транспорту і туристичної галузі України. Вісник економіки транспорту i промисловості. - № 41, 2013. - С. 114-117.

17. Писаревський, I. М. Туризм як національний пріоритет : монографія / I. М. Писаревський. - Харків : ХНАМГ, 2010. $284 \mathrm{c}$.

18. Стрілець, В. I. Організація залізничного туризму в Україні як чинник підвищення прибутковості галузі / В. І. Стрілець, О. Ф. Ялбуган // Зб. наук. праць. Дніпропетр. нац. ун-ту зал. трансп. ім. акад. В. Лазаряна «Проблеми економіки трансп.». Дніпропетровськ, 2011. - Вип. 2. - С. 114-117.

19. Тишковець С. Туристична подорож Зарічненщиною / С. Тишковець // Полісся. - 2009. - $\mathrm{N} 28 / 23$ лип./. - С. 2.

20. Хаустова В.Є., Горбатова Є.Ф. Проблеми розвитку туристичної галузі в Україні. - Проблеми економіки. - №2, 2010 р. - С. 28-33.

21. Чорненька Н. В. Організація туристичної індустрії: Навчальний посібник, К.: Атіка, 2006. - 264 с.

22. Juan Gabriel Brida' Manuela Deidda, Manuela Pulina "Tourism and transport systems in mountain environments: analysis of the economic efficiency of cableways in South Tyrol». - Journal of 
Transport Geography. Volume 36, April 2014, Pages $1-11$.

23. Khanal B. R. Tourism inter-industry linkages in the Lao PDR economy: An input-output analysis / B. R. Khanal, C. Gan, S. Becken // Tourism Economics. -2014. - 20 (1). - P. 171194.
24. Pratt S. Economic linkages and impacts across the Talc. / S. Pratt // Annals of Tourism Research. - 2011. - 38 (2). - P. 630-650.

25. The impacts of Australia's departure tax: Tourism versus the economy? / Forsyth P., Dwyer L., Spurr R., Pham T. // Tourism Management. 2014. - 40. - P. 126-136.

Експерт редакційної колегії к.е.н., доцент УкрДУЗТ Боровик Ю.Т.

УДК 656.2.003.1

\title{
СТРАТЕГІЯ УПРАВЛІННЯ РЕФОРМУВАННЯМ ЗАЛІЗНИЧНИМ ТРАНСПОРТОМ УКРАЇНИ
}

\author{
Бараи Ю.С., д.е.н., професор, \\ Чаркіна Т. Ю., к.е.н., доцент (ДНУЗТ)
}

\begin{abstract}
Авторами удосконалено метод побудови організачійних структур управління Департаментів (Главків), побудованих за продуктовим принцииом замість існуючого регіонального, завдяки використанню якого вдалося скоротити ланцюг команд, зменшити ієрархію управлінських рівнів, організувати нові функиіональні підприємства та знизити експлуатаційні витрати на перевезення.

Впровадження нової організаційної структури управління дозволяе оптимізувати діяльність департаменту на різних рівнях управління, скоротити чисельність прачівників та підвищити продуктивність прачі

Ключові слова: залізничний транспорт; організаційна структура управління; стратегія управління
\end{abstract}

\section{СТРАТЕГИЯ УПРАВЛЕНИЯ РЕФОРМИРОВАНИЕМ ЖЕЛЕЗНОДОРОЖНЫМ ТРАНСПОРТОМ УКРАИНЫ}

Бараш Ю. С., д.э.н., профессор, Чаркина Т. Ю., к.э.н., доцент (ДНУЖТ)

\begin{abstract}
Авторами усовершенствован метод построения организаиионных структур управления Департаментом (Главком), организованных по продуктовому приниипу вместо существующего регионального, с помощью которого удалось сократить иепь команд, уменьшить иерархию управленческих уровней, организовать новые функииональные предприятия и снизить эксплуатаиионные затраты на перевозки.

Внедрение новой организачионной структуры управления позволяет оптимизировать деятельность департамента на разных уровнях управления, сократить численность работников $u$ поднять производительность труда.
\end{abstract}

Ключевые слова: железнодорожный транспорт; организационная структура управления; стратегия управления 